\title{
Analysis of Demographic Characteristics of Patients Admitted to the Emergency Department with Rabies Risk
}

Acil Servise Kuduz Riskiyle Başvuran Hastaların Demografik Özelliklerinin Analizi

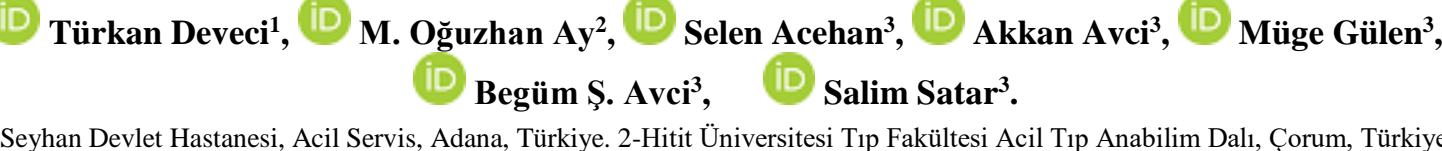

1-Seyhan Devlet Hastanesi, Acil Servis, Adana, Türkiye. 2-Hitit Üniversitesi Tıp Fakültesi Acil Tıp Anabilim Dalı, Çorun,
3-Sağlık Bilimleri Üniversitesi, Adana Şehir Eğitim ve Araştırma Hastanesi, Acil Tıp Kliniği, Adana, Türkiye.

\begin{abstract}
Objective: In this study, it was aimed to determine the demographic features of patients admitted to the emergency department with the rabies risky contacts.

Materials and Methods: Patients admitted toEmergency Medicine Department of Adana Numune Education and Research Hospital with rabies risky contacts between January 2012 and January 2014 were investigated from hospital automation system, emergency patient care cards and rabies notification book. SPSS 21.0 software package was used for statistical analysis of the obtained data.

Results: Total 2732 patients were included in the study. Of the patients, 70.4\% (1923 patients) were male and the median age was 23.65 years (min: 0, max: 87). It was determined that $15.7 \%$ of the patients admitted to the emergency department in 2012, 39.3\% in 2013 and 44.9\% in 2014. Admissions were more common in May, June and July. The most common history of rabies risky contact was with dogs (61.6\%) and via the bite (71.8\%). Of the patients, 99.9\% were given 1 dose, $85.6 \%$ were given 2 doses, $51.5 \%$ were given 3 doses, $9.9 \%$ were given 4 doses and $6.2 \%$ were given 5 doses of rabies vaccine, and $7.9 \%$ of them were given HRIG. Of the rabies risky animals, $99.7 \%$ were lived during the follow-up of, while $0.3 \%$ were died. None of the patients had symptoms of rabies and died.

Conclusion: This study showed that contact with rabies suspected animals is increasing in every year and it is still a serious public health problem for our city. More emphasis should be given to collecting stray animals, the control and rehabilitation of these animals carried out by municipalities. The number and capacity of the animal shelters should be increased, and the community should be informed about rabies

ÖZET
\end{abstract}

Amaç: Bu üç ylllık çalışmamızda acil servisimize başvuran kuduz riskli temas olgularının demografik özelliklerini değerlendirmeyi amaçladık.

Gereç ve Yöntem: 2012-2014 yılları arasında kuduz riskli temas nedeniyle acil servisimize başvuran hastaların demografik özellikleri hastane otomasyon sistemi, acil hasta bakı kartlart ve kuduz bildirim defterinden geriye dönük olarak incelendi. Elde edilen verilerin istatistiksel analizinde SPSS 21.0 paket programı kullanilds.

Bulgular: Calıșmaya 2732 hasta dâhil edildi. Hastaların \%70,4'ü (n:1923) erkek, \%29,6’st (n:809) kadın ve ortalama yaşı 23,65 yll (min: 0, maks: 87 yll) idi. Hastaların \%15,7'sinin 2012 yllında, \%39,3'ünün 2013 yllında, \%44,9'unun ise 2014 yll içinde acil servise başvurduğu belirlendi. Başvurular en sik mayıs, haziran ve temmuz aylarında idi. En slk kuduz süphesi olan hastalarda köpeklerle $(\% 61,6)$ ve istrlma yoluyla $(\% 71,8)$ temas öyküsü mevcuttu. Hastalartn \%95,5'ine yara bakımı ve tetanoz profilaksisi uygulanmiștr. Hastaların \%99,9'una 1 doz, \%85,6'sina 2 doz, \%51,5'ine 3 doz, \%9,9'una 4 doz ve $\% 6,2$ 'sine 5 doz aşı, \%7,9'una kuduz aşlssyla birlikte HRIG yapıldiğı saptandı. Hayvanların \%99,7'sinin takip süresince yaşadı̆̆ı, \%0,3 'ünün ise öldü̆ğ̈ tespit edildi. Hiçbir hastamızda kuduz hastalı̆̆ belirtileri ve ölüm görülmedi.

Sonuç: Bu çalıșma ile kuduz süpheli hayvanla temasın her geçen yll artış gösterdiği ve ilimiz için halen ciddi bir halk sağlığı sorunu olduğu belirlendi. Belediyelerce yürütülen sahipsiz hayvan toplama, kontrol ve ıslah hizmetlerine daha fazla önem verilmesi, hayvan barinaklarının kapasite ve sayılarının artturlmasl, toplumun kuduz hastalı̆g açısından bilgilendirilmesi gerekmektedir.

\section{GíRiş}

Birçok ülkede yaygın olarak görülen kuduz (rabies), nörotropik RNA virüslerinden Rhabdoviridea ailesi Lyssavirus cinsi virüsler ile bulaşan önlenebilir zoonotik bir enfeksiyondur $(1,2)$. Kuduz virüsü ile oluşan hastalık 2 farklı epidemiyolojik formda bulunur. Birincisi genellikle köpekler ve kedigillerden bulaşmanın ön planda olduğu ve öncelikle gelişmekte olan ülkelerde görülen formdur. İkincisi ise salvatik form olup Amerika Birleşik Devletleri örneğinde olduğu gibi, gelişmiş ülkelerde rastlanan, yarasa gibi çok farklı hayvan türlerinden ve genelde yaban hayvanlarından, inhalasyon yolu ile bulaşmanın olduğu şekildir (3). Kuduz hastalı̆̆ının en önemli bulaş yolu enfekte hayvanların 1sır1kları olup ensefalit ile sonuçlanmaktadır (4). Dünya Sağlık Örgütü'nün

Correspondence: Akkan Avcı, Sağlık Bilimleri Üniversitesi, Adana Şehir Eğitim ve Araştırma Hastanesi, Acil Tıp Kliniği, Adana, Türkiye. Email: drakkanavci@gmail.com Phone: +90 5334230369

Cite this article as: Deveci T, Avcı BŞ, Acehan S, Avcı A, Gülen M, Ay MO, Satar S. Analysis of Demographic Characteristics of Patients Admitted to the Emergency Department with Rabies Risk. Phnx Med J. 2020;2(1):41-45. 
(DSÖ) verilerine göre enfeksiyonun endemik olduğu şehirlerde yaklaşık yıllık 55.000 hasta kuduz hastalığ 1 nedeniyle hayatını kaybetmektedir. $\mathrm{Bu}$ ölümlerin \%56's1 Asya'da, \%44'ü Afrika'da meydana gelmekte olup, genel olarak büyük bir kısmı ise (\%84) ülkemizin de aralarında bulunduğu gelişmemiş ve gelişen ülkelerde ortaya çıkmaktadır. Dünya genelinde yaklaşık 10 milyon kişiye kuduz şüpheli 1 sırık sebebiyle koruma uygulanmaktadır. Ülkemizde yıllık 167 bin kişi kuduz şüpheli 1sırık sebebiyle sağlık kuruluşlarına başvurmaktadır. Ülkemizde kuduza bağlı her yıl bir ile üç kişi yaşamını kaybetmektedir (5-8).

Biz bu çalışmamızda acil servisimize başvuran kuduz riskli temas olgularının demografik özelliklerini son literatür verileri ışığında değerlendirmeyi amaçladık.

\section{GEREÇ VE YÖNTEM}

Bu çalışmada Adana Numune Eğitim ve Araştırma Hastanesi Acil Tıp Kliniğine Ocak 2012- Ocak 2014 tarihleri arasında kuduz riskli temas nedeniyle başvuran hastaların kayıtlarının geriye dönük olarak incelenerek kuduz riskli temas olgularının demografik özelliklerinin tanımlanması planlandı. Çalışmaya hastane Etik Kurulu'ndan izin alındiktan sonra başlandı. Her yaş grubundan ve her iki cinsiyetten acil servisimize başvuran, çalışma verilerine eksiksiz ulaşılabilen ve hastane otomasyon sistemine kayitlı tüm hastalar bu çalışmaya dâhil edildi. Çalışma verilerine eksiksiz ulaşılamayan hastalar çalışma dış1 bırakıldı. Standart veri giriş formu oluşturuldu. Hastane otomasyon sistemi, acil hasta bakı kartları ve kuduz bildirim defteri incelendi. Hastaların yaş, cinsiyet, şüpheli temas zamanı, temas tipi, hayvanın cinsi, hayvanın yaşayıp/yaşamadığı, 1sırılan kişiye profilaksi uygulanıp/uygulanmadığı, profilaksi için yapılan tedavi (aşı, hiperimmün kuduz serumu (HRIG)) ve uygulanan aşı dozu kaydedildi.

Çalışmada elde edilen verilerin istatistiksel analizinde SPSS 21.0 paket programı kullanıldı. Verilerin tanımlayıcı istatistiklerinde ortalama, standart sapma, medyan, minmaks, oran ve frekans değerleri kullanıldı. Değişkenlerin dağılımı kolmogorov simirnov testi ile kontrol edildi. Nicel verilerin analizinde bağımsız örnekleme $\mathrm{t}$ test kullanıldı. Niteliksel verilerin analizinde ki-kare testi kullanıldı. İstatistiksel olarak $\mathrm{p}<0.05$ değeri anlamlı kabul edildi.

\section{BULGULAR}

Çalışmamıza kuduz şüphesi olan hayvanlarla temas ile acil servise başvuran toplam 2732 hasta dâhil edildi. Hastaların \%70,4'ü (n:1923) erkek, \%29,6's1 (n:809) kadın cinsiyette idi. Hastaların yaş ortalaması 23,65 yıl (min:0, maks:87 y1l) idi. Erkeklerin yaş ortalaması 23,48 yıl, kadınların 24,03 yıl idi. Hastaların en sık ilk iki dekad içerisinde kuduz şüphesi olan hayvanlarla temas ettikleri tespit edildi (Tablo 1).

Çalışmaya alınan hastaların \%15,7'sinin (n:430) 2012 yılında, \%39,3'ünün (n:1075) 2013 yılında, \%44,9'unun (n:1227) ise 2014 yılı içinde acil servise
Tablo 1: Hastaların yaş gruplarına (dekad) göre dağılımı

\begin{tabular}{|c|c|c|}
\hline Yaş (yıl) & $\mathbf{n}$ & $\mathbf{\%}$ \\
\hline $0-10$ & 927 & 34 \\
\hline $11-20$ & 557 & 20,4 \\
\hline $21-30$ & 360 & 13,2 \\
$31-40$ & 298 & 11 \\
\hline $41-50$ & 262 & 9,6 \\
\hline $51-60$ & 189 & 6,9 \\
\hline $61-70$ & 97 & 3,5 \\
\hline $71-80$ & 32 & 1,1 \\
\hline $81-90$ & 9 & 0,3 \\
\hline Toplam & $\mathbf{2 7 3 2}$ & $\mathbf{1 0 0}$ \\
\hline
\end{tabular}

Tablo 2: Kuduz şüphesi olan hayvanlarla temas türü

\begin{tabular}{|l|c|c|}
\hline Temas Türü & $\mathbf{n}$ & $\mathbf{\%}$ \\
\hline Isırılma & 1961 & 71,8 \\
\hline Tırmalanma & 759 & 27,8 \\
\hline $\begin{array}{l}\text { Açık yara ile } \\
\text { temas } \\
\text { Diğer }\end{array}$ & 2 & 0,07 \\
\hline Toplam & $\mathbf{2 7 3 2}$ & $\mathbf{1 0 0}$ \\
\hline
\end{tabular}

Tablo 3: Hastaların kuduz şüpheli hayvanla temas1 sonrası acil servise başvuru zamanı (gün)

\begin{tabular}{|c|c|c|}
$\begin{array}{c}\text { Temas sonrası } \\
\text { başvuru } \\
\text { zamanı (gün) } \\
\text { Aynı gün }\end{array}$ & 2297 & $\mathbf{n}$ \\
\hline $1-3$ & 396 & 14,5 \\
\hline $4-7$ & 29 & 1,06 \\
\hline $8-14$ & 9 & 0,33 \\
\hline $15-28$ & 1 & 0,04 \\
\hline Toplam & $\mathbf{2 7 3 2}$ & $\mathbf{1 0 0}$ \\
\hline
\end{tabular}

kuduz şüpheli hayvanlarla temas şikâyetiyle başvurdukları ve başvuruların yıllara göre giderek artış gösterdiği tespit edildi. Hastanemiz otomasyon sisteminin kayıtlarını incelediğimizde acil servise tüm 
başvurular içindeki kuduz riskli hayvanlarla temas eden hasta oranının da 2012 yılında \%0,16; 2013 y1lında \%0,32 ve 2014 yılında \%0,31 olduğu belirlendi. Acil servis başvuruların ise en sık mayıs, haziran ve temmuz aylarında olduğu görüldü.

Kuduz şüphesi olan hayvan türleri incelendiğinde temasin en sik \%61,6 (n:1684) ile köpek ve \%36,9 (n:1009) ile kedi olduğu tespit edildi. \%1,5 (n:39) hastada ise yarasa gibi diğer hayvanlarla temas olduğu görüldü. Hastaların \%55,9'unun (n:1526) köpekler tarafindan 1sırıldığı, \%5,5'inin (n:151) köpekler tarafından tırmalandığ tarafından tırmalandığ 1 \% 14,8'inin (n:403) kediler tarafindan 1sirıldığ 1 saptandi. Temas tipi ile temas edilen hayvan türü arasında istatistiksel olarak anlamlı farklılık olduğu belirlendi ( $\mathrm{p}<0.001)$.

Erkek hastaların \%77,6’sının (n:1307) kuduz şüphesi olan köpeklerle, kadın hastaların ise \%51,7'sinin (n:418) kuduz şüphesi olan kedilerle temas ettiği tespit edildi. Erkek ve kadın cinsiyetler arasında temasta bulunulan hayvan türü açısından istatistiksel olarak anlamlı fark olduğu tespit edildi $(\mathrm{p}<0.001)$.

Hastaların \%71,8'inin (n:1961) 1sırılma yoluyla, \%27,8'inin (n:759) ise tırmalanma yoluyla kuduz şüphesi olan hayvanlarla temas ettiği saptandı (Tablo 2). Erkeklerin \%76,2'sinin (n:1465) 1sırıldığ1, \%23,4'ünün (n:450) tırmalandığ \%61,3'ünün (n:496) 1sırıldı̆̆ı, \%38,2'sinin (n:309) tırmalandığ 1 ve cinsiyetler arasında temas tipi açısından istatistiksel olarak anlamlı derecede fark olduğu tespit edildi ( $\mathrm{p}<0.001)$.

Hastaların \%84,1'inin (n:2297) temas sonrası aynı gün içinde, \%14,5'inin (n:396 hasta) ise temas sonrası 1-3 gün arasında acil servise başvurdukları tespit edildi (Tablo 3). Kuduz şüphesi olan hayvanlarca 1sırılan hastaların temas sonrası aynı gün acil servise başvuru zamanının tırmalananlara göre daha fazla olduğu, 1-3. günler arasında başvurunun ise tırmalananlarda daha fazla olduğu görüldü ( $\mathrm{p}=0.032)$ (Tablo 4).

Kuduz şüpheli hayvanlarla temasta bulunan hastaların \%95,9'una (n:2621) yara bakımı, tetanoz profilaksisi yapıldığı tespit edildi. Hastaların \%99,9'una (n:2728) ilk doz kuduz aşısının, \%85,6'sına (n:2338) 2. doz kuduz aşısının, \%51,5'ine (n:1408) 3. Doz kuduz aşısının, \%9,9’una (n:271) 4. doz kuduz aşısının, \%6,2'sine (n:169) 5. doz kuduz aşısının yapıldığı belirlendi.

Hastaların sadece \%7,9'una (n:215) kuduz antiserumu verildiği saptand. Kuduz antiserumu verilen hastalara ortalama 2575,26 \pm 1082,476 IU kuduz antiserumu verilmiş idi. Kuduz şüphesi olan köpeklerle temas eden hastaların \%10,1'ine (n:170), kedilerle temas edenlerin ise \%4,2'sine (n:42) kuduz antiserumu verildiği belirlendi. Kuduz şüphesi olan köpek ve kediler ile temasta bulunan hastalar arasinda kuduz antiserumu verilmesi açısından istatistiksel olarak anlamlı farklılık mevcut idi $(\mathrm{p}<0.001)$. Kuduz şüphesi olan hayvanlar tarafindan isirılan hastaların \%9,9'una (n:195), tırmalanan hastaların ise \%2,6'sina (n:20) kuduz antiserumu verildiği ve isırılan ve tırmalanan hastalar arasında kuduz antiserumu verilmesi açısından istatistiksel olarak anlamlı farklılık olduğu görüldü $(\mathrm{p}<0.001)$. Erkek hastaların \%8,6'sına (n:165), kadınların \%6,2'sine (n:50) kuduz antiserumu verildiği ve cinsiyetler arasında kuduz antiserumu verilme oranı açısından istatistiksel olarak anlamlı derecede fark olduğu $(\mathrm{p}=0.035)$ görüldü.

Şüpheli temasta bulunulan hayvanların takibinde \%99,7'sinin (n:2725 hayvan) yaşadığ $1, \% 0,3$ 'ünün (n:7 hayvan) öldüğünün görüldüğü belirlendi. Köpeklerin $\% 0,2$ 'sinin (n:4) öldüğü, kedilerin \%0,3’ünün (n:3) öldüğü saptand1. Ölen hayvan türleri arasında istatistiksel olarak anlamlı farklılık yok idi $(\mathrm{p}=0.979)$. Çalışmaya alınan hastalarımızın hiçbirinde kuduz hastalığı belirtileri saptanmadı. Kuduz hastalığına bağlı ölen hastamizda yoktu.

\section{TARTIŞMA}

Kuduz evcil ve vahşi hayvanlar tarafindan bulaştırılan ve hastalığın belirtilerinden herhangi biri gelişince hem insan hem hayvan için öldürücü olan zoonotik bir viral hastalıktır (9). Yapılan çalışmalarda en az maruziyetin $0-5$ yaş aralığında $(\% 9,3-\% 11,2)$ ve 46 yaş üzerinde (\%9-\%10,4) olduğu bildirilmiştir $(10,11)$. Bizim çalışmamızda kuduz şüpheli hayvanlarla temasların en çok ilk 2 dekad içerisinde olması, bu yaş aralığında çocuk ve genç erişkinlerin okul ve sosyal aktiviteler

Tablo 4: Hastaların kuduz şüpheli hayvanla temas tipine göre acil servise başvuru zamanlarının (gün) karşılaştırılması

\begin{tabular}{|c|c|c|c|c|c|}
\hline \multirow{2}{*}{$\begin{array}{l}\text { Temas sonrası } \\
\text { başvuru zamanı } \\
\text { (gün) }\end{array}$} & \multicolumn{2}{|c|}{ Isırılma } & \multicolumn{2}{|c|}{ Tirmalama } & \multirow[b]{2}{*}{$\mathbf{p}$} \\
\hline & $\mathbf{n}$ & $\%$ & $\mathbf{n}$ & $\%$ & \\
\hline Aynı gün & 1675 & 85,4 & 616 & 81,2 & \multirow{5}{*}{0,032} \\
\hline $1-3$ & 260 & 13,3 & 130 & 17,1 & \\
\hline $4-7$ & 19 & 1 & 10 & 1,3 & \\
\hline $8-14$ & 7 & 0,4 & 2 & 0,3 & \\
\hline $15-28$ & 0 & 0 & 1 & 0,1 & \\
\hline
\end{tabular}




\section{Deveci et al.}

nedeniyle daha çok dışarıda olmaları, hayvanlara ilgi duymaları, onlarla oyun oynamak ve sevmek istemelerinden kaynaklanabilir. Özellikle oyun ve okul çağındaki çocukların aile ve okulda eğitimlerle bilinçlendirilmesi maruziyetleri önemli ölçüde azaltabilir. Çalışmamıza göre en az maruziyetin 61 yaş sonrasında olması ise bu yaş grubundaki insanların çalışma hayatında daha az aktif rol almaları ve olası sağlık problemleri nedeniyle kuduz şüpheli hayvanlarla daha az temasta bulunmalarına bağlı olabilir.

Çalışmamızdaki hastalarımızın çoğunluğunun erkek olması ülkemizde faklı illerde yapılan diğer çalışmalarla benzerlik göstermektedir (12). Erkeklerin kadınlara oranla toplumumuzda daha aktif sosyal role sahip olmaları, kuduz şüpheli hayvanlarla temas halinde diğer aile bireylerini koruma kollama amaçlı atılmaları erkek cinsiyette kuduz şüpheli hayvanlarla temas oranını artırmış olabilir.

Çalışmamızda acil servise başvuran hasta sayısının her geçen yıl artmasıyla beraber kuduz riskli hayvanlarla temas nedeniyle başvuran hasta oranında da ciddi artış olduğu tespit edildi. $\mathrm{Bu}$ durum belediyelerce hayvan toplama ve kontrol hizmetlerinin aksatılmasına, kuduz riskli hayvanlara yönelik hayvan ıslah ve aşılama faaliyetlerinin ihmal edilmesine bağlı olabilir. Bir diğer etki insanların hayvan sevgisi yönünden bilinçlenmesi, sokak hayvanlarını beslemek için çaba sarf ederken temasta bulunması ve bu temasin farklı boyutlara geçmesidir.

Mevsimlere göre kuduz şüpheli temas olgu dağı̆lımına bakıldığında en fazla başvurunun literatürdeki çalışmalara benzer şekilde ilkbahar sonu ve yaz aylarında olduğu görüldü. $\mathrm{Bu}$ dönemde hava sıcaklıklarının artmasıyla insanların dışarıda geçirdikleri zamana paralel olarak kuduz şüpheli hayvanlarla temas oranı artmış olabilir. Ayrıca yaz aylarında okulların tatil döneminde olması nedeniyle okul dönemi çocuklarında kuduz şüpheli hayvanlarla temas oranında artış görülmüş olabilir.

Çalışmamızda literatürle uyumlu olarak temas edilen kuduz şüpheli hayvanların büyük çoğunlukla köpekler ve kedilerdi $(13,14)$. Bu durum yerel yönetimlerin özellikle bu hayvanların denetiminde yetersiz kaldığını, hayvan toplama, sslah ve aşlama faaliyetlerine daha fazla önem verilmesi gerektiğini düşündürmektedir.

Kuduzun insan ve hayvanlara bulaşmasında en önemli yol tırmalama, 1sırma gibi durumlarla enfekte salyanın doğrudan temasıdır. Direk 1sırık olmaksızın temasla gelişen kuduz vakaları çok nadirdir (15). Bizim çalışmamızda ısırılma vakaları çoğunluktaydı.

Çalışmamızda erkeklerin köpeklerle, kadınların ise kedilerle daha fazla temas ettiği tespit edildi. Bu sonuç erkeklerin köpeklere, kadınların ise kedilere daha fazla ilgi duymaları ve temasta bulunmalarına bağlı olabilir.
Çalışmamızdaki olguların literatürle uyumlu olarak çoğunluğunun ilk 24 saatte içinde acile başvurdukları görüldü (16). Şüpheli hayvanla temas sonrası aynı gün acil servise başvurma oranlarının yüksek olması hastaların kuduzun ölümcül hastalık olduğunu düşünmeleri ve ölüm korkusuyla büyük oranda aynı gün acil servise başvurmalarına bağlı olabilir. Temas sonrası aynı gün acil servise başvuru oranının 1sırılanlarda tırmalananlardan fazla olduğu, 1-3. günler arasında başvurunun ise tırmalananlarda istatistiksel olarak anlamlı derecede daha fazla olduğu görüldü. Muhtemelen tırmalananların isırılan hastalardan daha az kuduz riskine sahip olduğu düşünülmüş ve tırmalananlar aynı gün başvurmayıp başvuruyu geciktirmiş olabilir.

Kuduz ile teması olan hastalara erken dönemde lokal yara tedavisi yapılması, 1sırılan bölgenin su ve sabun ile acilen yıkanması, gerekli hallerde tetanoz profilaksisi ve bakteriyel enfeksiyonlar için antimikrobiyal tedavi uygulanmasi hayat kurtarıcidır (17). Bundan sonraki aşama, DSÖ tarafindan önerilen hücre kültürü aşısı ve hiperimmün kuduz serumu (HRIG) uygulaması acil profilaktik bir yaklaşımdır ve hayat kurtarıcı olabilir (18). Ülkemizde aşılanma oranı oldukça yüksek olmasına rağmen hayvan toplama ve ıslah çalışmasının iyi yapıldığı ABD gibi ülkelerde aşılama oranının sadece $\% 6,7$ olduğu bildirilmiştir (19). Kuduza maruz kalan hastalarda uygun yara bakımı sonrası insan diploid hücre aşısı ile birlikte HRIG uygulanması insan ölümünü neredeyse $\% 100$ önler (20). Az gelişmiş ülkelerde aşıyla birlikte serum uygulaması \%10'un altındadır. Çalışmamızda olduğu gibi ülkemizde yapılan diğer benzer çalışmalarda da kuduz HRIG uygulaması oranının düşük olduğu görülmüştür $(10,11,16)$. Çalışmamızda köpeklerle temas eden ve isırılan hastalara kuduz HRIG yapılma oranı yüksek tespit edilmiş olup köpek ısırıklarının daha ciddi ve daha derin cilt ve mukoza yaralanmasina sebebiyet vermesinin HRIG yapılma oranını yükselttiğini düşünmekteyiz.

Etkin ve zamanında aşılama sayesinde çalışmamızda hiçbir hastamızda kuduz hastalı̆g belirtilerine ve kuduz hastalığına bağlı insan ölümüne rastlanmadığını düşünmekteyiz.

Sonuç olarak; Kuduz, maruziyetten sonra çok etkili bir şekilde önlenebilir. Hastallğ önlemede evcil hayvanları kuduza karşı aşılama ve vahşi ya da başıboş hayvanlarla temastan kaçınmak en etkili yöntemdir. Kuduz riskli hayvanla temas sonrası yaraya bulaşmış olan virüsün organizmaya girişini engellemek için hastaların en kısa sürede hastaneye başvurmaları ve temas sonrası etkin yara bakımı ve zamanında uygun aş1 ve/veya immünoglobülin ile koruma önem arz etmektedir. 
Phnx Med J. March, Volume 2 No 1

\section{KAYNAKLAR}

1. World Health Organization. WHO expert consultation on rabies. WHO Tech Rep Ser 2005; Abstract 931, pg. 88. 2. Erişim: http://whqlibdoc.who.int/trs/WHO_TRS_931_eng.pdf.

2. Fauquet CM, Mayo MA, Maniloff J, et al. Virus Taxonomy. Eighth report of the international committee on the nomenclature of viruses. Elsevier Academic Press, Inc. San Diego, CA. 2005.

3. Kanra G, Kara A. Kuduz; patogenez, tanı ve profilaksi. Hacettepe Tip Dergisi. 2001; 32: 114124.

4. Warrell MJ, Warrell DA. Rabies and other lyssa virus diseasse. Lancet 2004; 363(9413):959-69.

5. WHO Expert Consultataion on Rabies. WHO Technical Report Series No: 931. First report. pp. 1-106.World Health Organization, Genova, Switzerland, 2005. (15.02.2010 tarihinde yüklenmiştir http://www.who.int/rabies/trs931_\%2006_05.pdf)

6. Child EJ, Noah ZD, Rupprecht EC. Rabies. In: Gorbach SL, Bartlett JG, Blacklow NR, Infectious Diseases. pp.1545-59, 2nd Ed. W. B. Saunders Company. Philadelphia, USA,1998.

7. Bassin SL, Rupprecht CE, Bleck TP. Rhabdoviruses. In: Mandell, Doglas and Bennett's Principles and Practice of Infectious Diseases, pp 2249-2258. 7th. Ed. Churchill Livingstone, New York, USA, 2010.

8. Büke M, Büke AÇ, Topçu AW. İnfeksiyon Hastalıkları ve Mikrobiyolojisi s.1029-104, Nobel Tıp Kitabevleri, İstanbul, 2002.

9. Nesanır N. Türkiye’de Henüz Çözülemeyen Bir Sorun: Kuduz Riskli Temas Olguları. Sted 2006; 15: 202-6.

10. Söğüt Ö, Sayhan MB, Gokdemir MT, Kara HP. Türkiye’nin Güneydoğusunda Önlenebilir Bir Halk Sağlı̆ğ Sorunu: Kuduz Riskli Temas Olguları. JAEM 2011;1(10):14-7.

11. Temiz H, Akkoç H. Diyarbakır Devlet Hastanesi Kuduz Aşı Merkezine Başvuran 809 Olgunun Değerlendirilmesi. Dicle Tıp Dergis 2008;35(3):181-84.

12. Gülaçtı U, Üstün C, Gürger M, Şahan M, Satıcı Ö. Kuduz riskli temas vakalarının epidemiyolojisi ve kuduz proflaksisi uygulamasının değerlendirilmesi. Turkiye Klinikleri J Med Sci 2012;32(3): 759-65.

13. Ozsoy M, Yakıștıran S, Ozkan E. 2000 Yılında Kuduz Așı Merkezine başvuran hastaların değerlendirilmesi. Turk Hijyen ve Deneysel Biyoloji Dergisi 2002; 59:1-5.

14. Buzgan T, Irmak H, Y1lmaz GR, Torunoğlu MA, Safran A. Epidemiology of human rabies in Turkey:1992-2007. Turk J Med Sci 2009;39(4):591-97.

15. Çalangu S, Töreci K, Aktuğlu Y. Kuduzdan Korunma. Klimik Dergisi 1988; 1(2): 24-39.

16. Göktaş F, Ceren N, Karagül E, Çiçek G, Özyürek S. Kuduz aşı merkezine başvuran 11017 olgunun değerlendirilmesi. Klimik dergisi 2002;15(1):12-15

17. World survey of rabies, 1997. Wkly Epidemiol Rec. 1999; 74: 381-384.

18. Centers for Disease Control and Prevention. Human rabies prevention-United States 1999: Recommendations of the Immunization Practices Advisory Committee (ACIP). MMWR Morb Mortal Wkly Rep 1999; 44(RR-1): 1-40.

19. Moran GJ, Talan DA, Mower W, et al. Appropriateness of rabies postexposure prophylaxis treatment for animal exposures. JAMA 2000; 284: 1001-1007.

20. Abubakar SA, Bakari AG. Incidence of dog bite injuries and clinical rabies in atertiary health care institution: A 10-year retrospective study. Annals of African Medicine 2012;11 (2):108-11. 